\title{
OLD ENGLISH SIMILE OF EQUALITY: THE HIGHEST DEGREE OF SIMILARITY
}

\author{
MARIANA OLENIAK \\ Vasyl' Stus Donetsk National University, Ukraine \\ maryana@mail.org
}

\begin{abstract}
This paper aims to provide an account of Old English similes of equality marked by the superlative degree of the adjective gelic. It deals with the structure and semantics of similes marked by the (ge)/(on)licost component, which, unlike in Modern English, being subjected to gradation, can show the highest degree of similarity between referents. The article presents the criteria for structural classification of the simile in question describing two major structural types, that employ nouns in the dative or nominative case, as well as its semantic interpretation from macro and micro levels of perspective. The paper examines every simile with the (ge)/(on)licost component found in Old English manuscripts belonging to various textual genres.
\end{abstract}

Keywords: Old English, simile, tenor, vehicle, salient feature

\section{Introduction}

Considering a fine line between metaphor and simile one must admit that the former becomes the focus of analyses much more often than the latter not only in linguistics, but also in cognitive psychology, philosophy, literary theory and criticism. Even less is simile investigated in the earliest periods of the English language. To comprehend the scale of difference in the amount of research devoted to these tropes one could consider google search data, that offer about 261000 results for a "metaphor in English", 37000 results for a "simile in English" and only 2 results for a "simile in Old English". Orval (1951) studies Old English simile in poetry and emphasizes their scarcity. Cavill (1999) comes to the same conclusion. To the best knowledge of the author the only diachronic investigation of the structure of similes in Middle English was conducted by Nevanlinna (1993) based on the Helsinki corpus. There have also been some sporadic cases of simile analyses as a part of syntactical investigation of Old English comparative clauses or the dative case functioning (Baker (2012), Fisher (1992), Gergel (2008), McLaughlin (1983), Merritt (2013), Mitchel (1985)) as well as in the literary works of certain periods or some authors' works. Thus, Margolis (1957) draws a comparison between simile and related devises; Walker (2016), Beardsley (1981), Dawes (1998) study semantics of simile; Tyler (2006), highlights the poetics of the Old English literature providing some simile examples; Amodio (2014), 
Stodnick (2012), Trilling (2012) analyse and compare Old English translations and adaptations of Latin texts some of them containing similes.

This study aims to provide an account of every simile in Old English that contains the superlative degree of the Old English adjective gelic from the point of view of their structure and semantics. The data discussed are taken from the Old English corpus of University of Toronto employing a continuous sampling method. The Old English corpus of the University of Toronto contains at least one copy of every surviving Old English text, thus all existing cases of the abovementioned type of simile have been analysed. The whole corpus of the Old English similes of equality containing the superlative degree of a copulative lice contains 31 examples.

\section{The structure of the Old English simile with the (ge)/(on)licost component}

Simile has been the tool of rhetoric for ages. It surely should be recognized as being universal, used by all speakers irrespective of their nationality, but manifesting itself differently in different languages. Given that many Old English texts are translations or interpretations from Latin and can only be assigned the date of their creation depending on the survived manuscript, the author considers the Anglo-Saxon simile not so much as a manifestation of a personal craft, being an individually inspired production of a genius, but as a collective, participatory, intellectual and cultural output echoing with current life, conventions, and complying with the current system of information exchange.

Old English employs certain linguistic mechanisms to create simile of equality among which there is the use of the superlative degree of a copulative lice in a variety of structural combinations, for example:

(1)

Foran aeghwylc woes, <stiðra> noegla gehwylc, style gelicost, hoepenes

'Before each was $<$ stiff $>$ claw-nail, to steel most like, heathen's

handsporu $<$ hilderinces $>$, egl', unheoru

banged up < $<$ worrior's $>$, grip not gentle'

The terms open/closed simile are usually used in the context of simile semantics investigations (Margolis 1957; Beardsley 1981; Dawes 1998; Walker 2016) but taking into account the fact that any changes in semantics trigger corresponding changes of form, we will use these characteristics of simile as a useful criteria to organize all the structures of similes under consideration into a consistent paradigm. The criteria for our structural classification are: 1) the case of the noun used as a vehicle; 2) the amount of the simile components explicated in the surface structure: three (tenor, vehicle and a comparison marker) or all four (tenor, vehicle, comparison marker and a common salient feature shared by the tenor and the vehicle); 3) their grammatical expression; 4) their positioning. 
Notwithstanding the fact that Old English was a highly-inflected language with a relatively free word order, we can observe a strong tendency to place the topic in a preposition in respect to the vehicle (1) though there are some instances of the contrary situation as in Beowulf:

(2)

... him of eagum stod ligge gelicost leoht unfaeger.

'...from his eyes stood to a flame most like light horrible.'

The positioning of the comparison marker was not regulated by hard-and-fast rules: it can either precede (example 11) (33\% of examples) or follow the vehicle (example 1) (67\% of examples) but it never occurs in the initial position within the simile construction and it is always in contact position with the vehicle whilst other simile components can be either in contact (example 4) or in a distant position (example 3) relating to one another. The spelling of it is rather inconsistent and sometimes idiosyncratic since six different variants have been registered: gelicost -21 examples $(67,7 \%)$, geliccost -2 examples $(6,5 \%)$, geliccast -1 example (3,2\%), gelicast - 4 examples (13\%), gelicust - 1 example $(3,2 \%)$, olnicost -1 example $(3,2 \%)$ and licost -1 example $(3,2 \%)$. The position of the comparison marker defines the case of the noun or the pronoun used as a vehicle: if it follows the vehicle, the latter is used in the dative case (example 6), if it proceeds the vehicle, the latter is used in the nominative case (example 10). It is worth mentioning that the combination of the dative case and a superlative degree of lice was highly productive in the Old English simile formation: It constitutes 27 out of 31 examples, which is $90 \%$ of the sampling.

The whole scope of similes in question can be classified into two major structural types with the further subdivision: 1) Old English similes with the gelicost component employing a noun in the dative case as a vehicle; 2) Old English similes with the gelicost component employing a noun in the nominative case as a vehicle.

\subsection{Old English similes with the gelicost component employing a noun in the dative case as a vehicle}

The basic structure for the majority of Old English similes containing different grammatical forms of a copulative lice is $\mathrm{N} /$ Pron $+\mathrm{N}_{\text {dat }}+$ gelicost. Similes employing a noun in the dative case as a vehicle can start with either a tenor or a vehicle and, thus, can be subdivided into two subtypes.

\subsubsection{The distinctive feature of the first structural subtype of the Old English similes with the gelicost component is that it starts with a tenor.}

It can be either open (when it does not explicate a common feature shared by the topic and the vehicle of the simile: subtypes of 2.1.1.1.) or closed (when it explicates a common feature shared by the topic and the vehicle: subtypes of 
2.1.1.2.). Being open, it consists of three elements: the first component can be either a noun or a pronoun representing the tenor of the simile, the second component is a noun in the dative case being the vehicle of it and the third one is the comparison marker. The empirical material gives the reason to divide this structural type into two subtypes. The first is the basic structure proper:

2.1.1.1. Open simile of the structure: $N /$ Pron $+N_{\text {dat }}+$ gelicost.

Open simile of the structure: $\mathrm{N} /$ Pron $+\mathrm{N}_{\text {dat }}+$ gelicost can be devided into two subtypes.

a) The first subtype represents the basic structure proper: $\mathrm{N} /$ Pron $+\mathrm{N}_{\mathrm{dat}}+$ gelicost

(3)

Word spearcum fleah attre gelicost, ponne he ut porhdraf: "Eala drihtenes prym

'Words in sparks flew out to poison most like, when he exploded: "Alas the Lord's glory!"

In the example (3) taken from "Christ and Satan", that, presumably, dates back to the 7-th century, "the words" are compared to "poison" with no salient feature explication. The distant position of the tenor and the vehicle in this structural type was optional.

b) The second subtype of this structure is extended by a noun phrase that specifies the vehicle but cannot be regarded as an explicit commonly shared feature since it is not semantically specific enough to derive this property: $\mathrm{N}+\mathrm{N}_{\mathrm{dat}}+$ gelicost $+\mathrm{NP}(\mathrm{Adj}+\mathrm{N}+$ clause $)$

(4)

Is seo eaggebyrd stearc ond hiwe stane gelicast, gladum gimme, ponne in goldfate

'Is that bird's eye piercing and of colour to stone most like, a bright gem,

smipa orponcum biseted weorped.

when by a skillful smiths' in beaten-out gold is set.'

This structural type is very similar to the first one, but the vehicle here is further specified by an extended noun phrase. Thus, the colour of the eye is not just compared to any stone, but a stone, which is a bright gem, and not just any bright gem, but the one that is skilfully put into gold. The colour in question is not mentioned though, so, notwithstanding an extended specification of the kind of the gem, the simile cannot be considered a closed one.

\subsubsection{Closed simile of the structure: $N /$ Pron $+N_{\text {dat }}+$ gelicost.}

If a simile of this structural type is closed, the composition of it is complicated by additional lexemes, phrases or clauses which are the verbalisation of the concept making the simile closed (further in the text they are typed in bold). Four subtypes of such a structure can be singled out.

a) $\mathrm{N}+\mathbf{A d j}+\mathrm{N}_{\mathrm{dat}}+$ gelicost + clause 
(5)

se engel becwom, windig and wynsum, wedere gelicost ponne hit on

'... angel descended, windy and pleasant, to weather most like, when in the summer season

sumeres tid sended weorðeð dropena drearung on dages hwile, wearmlic wolcna scur.

drops of rains are sent falling during the day, and warm showers from the heavens.'

This structural type is based on the structure $\mathrm{N} /$ Pron $+\mathrm{N}_{\text {dat }}+$ gelicost; with the additional adjectives used between the tenor and the vehicle that explicate the commonly shared features, besides, the clause is considered to be a part of the simile since it specifies the vehicle. So, in the example, given above, an angel is compared to breezy summer weather on the grounds that both of them are windy and pleasant.

b) $\mathrm{N}+\mathbf{V} / \mathbf{V P}+\mathrm{N}_{\mathrm{dat}}+$ gelicost

The structural subtype in question is quite a productive one. What differentiates it from the previously described ones is that the salient feature, shared by the topic and the vehicle, is expressed either by a verb or a verb phrase and not by an adjective.

(6)

Landes froetwe gewitap under wolcnum winde geliccost.

'The lands will depart under the sky, to the wind most like.'

In this 9-th century example taken from "The Phoenix" the land is compared to wind since both can depart, though the character of the departure is not quite clear: whether or not the departure is fast or intangible or temporary, etc.

c) clause $+\mathrm{N}+\mathrm{N}_{\mathrm{dat}}+$ gelicost

(7)

"Gewat pa ofer waegholm, winde gefysed, flota famiheals fugle gelicost..."

'Went over the sea of waves, by the wind driven, the foamy-necked floater to a bird most like...'

In (7) the author of Beowulf compares the ship to a bird since they, if moved by the wind, float on the water in a very similar way. Thus, he specifies the simile with a clause explaining why a ship and a bird are very much alike.

d) $\mathrm{N}+\mathrm{N}_{\text {dat }} /$ Pron $_{\text {dat }}+$ gelicost + clause

(8)

Het wapen wera wexe gelicost on pam orlege eall formeltan ....

'(he) let the weapons to be to wax most like, completely melt in that fight ...'

This structural subtype is similar to the previous one differing only in the positioning of the clause containing a commonly shared salient feature that is in 
postposition in this case. The given example shows the comparison of the weapon to wax having the same property - being able to melt entirely.

\subsubsection{The distinctive feature of the first structural subtype of the Old English similes with the gelicost component is that it starts with a vehicle.}

The distinctive feature of this structural subtype of the Old English similes with the gelicost component is that it starts with a vehicle: $\mathrm{N}_{\text {dat }}+$ gelicost + clause $/ \mathrm{N}_{\text {nom }} \mathrm{P}$ :

(9)

..... wundum weorðan, watre geliccost faran flode blod.

'...wound was made, to rain most like, flew floods of blood.'

Unlike all the other structural types, this one opens with a vehicle that is followed by the gelicost and the clause containing the tenor. Thus, the (9) shows the similarity between the flowing of blood and the rain, placing the dative case of the noun "rain" in preposition to the comparison marker and the tenor.

All the previously described structural types employed a noun in the dative case to mark the vehicle of the simile. The author will further proceed with the cases in which the vehicle of the simile is expressed by a noun in the nominative case. The following structural types display only closed similes.

\subsection{Old English similes with the gelicost component employing a noun in the nominative case as a vehicle.}

The distinctive feature of the second structural type of the Old English similes with the gelicost component is that it employs a noun in the nominative case as a vehicle. It can be subdivided into two subtypes depending on the grammatical function of a vehicle and a verbalized ground of the simile.

\subsubsection{Vehicle is a separate noun further specified by a clause}

In the first subtype of the structural type in question the vehicle is expressed by a separate noun further specified by a clause: $\mathrm{N}+\mathbf{A d j}+$ onlicost $+\mathrm{N}_{\text {nom }} \mathrm{P}$ ( $\mathrm{N}_{\text {nom }}+$ clause).

Se fugel is on hiwe aghwoes cenlic, onlicost pean, wynnum geweaxen,

'The bird in colour is in every way unique, most like to a peacock, grown

boes gewritu secgad.

with joys, of which writings speak'.

In (10) taken from "The Phoenix", the adjective cenlic 'unique' refers both to the colour of the phoenix and a peacock serving as a basis for their juxtaposition; the vehicle, that immediately goes after the comparison marker is extendedly 
specified by a clause, that is why the uniqueness of the colour of the bird is not just compared to any peacock, but to the one grown with joys, of which writings speak.

\subsubsection{Vehicle is the subject of the situation described by a clause}

This structural subtype differs from the others in the way that the vehicle of the structure is not expressed by a separate noun further specified by a clause, but it is the subject of the situation described by a clause that explains the common characteristics of the juxtaposed concepts. Being the subject of a clause, it is used in the nominative case: $\mathrm{N}+\mathbf{V}+$ gelicost + clause.

"\& his aefterfolgeras feowertiene gear hit sippan totugon \& $\underline{\text { totceron }}$

'and his fourteen successors and a year later took hold of them and tore

parm gelicost ponne seo leo bringð his hungregum hwelpum hwat to etanne..." them most like to when the lion brings his hungry cubs something to eat....'

The first element of this structural type is a noun, representing the tenor, the second is a verb, which is a commonly shared feature by the tenor and the vehicle, and, joined by the gelicost, the clause contains the vehicle of the simile in the nominative case describing the way in which the salient feature is realized. So, in the provided example from Orosius (11), that belongs to the late Old English period, people are compared to lion cubs on the grounds of performing an analogous action - tearing the object apart.

The statistical data of the singled out structural types of the Old English simile containing a gelicost component is shown in the Table 1.

Table 1. The structural types of the Old English simile of equality containing a gelicost component

\begin{tabular}{|c|c|c|}
\hline Type & & Amount \\
\hline 2.1. & \multicolumn{2}{|c|}{ Old English similes with the gelicost component employing a noun in the dative case } \\
\hline 2.1.1. & $\mathrm{N} /$ Pron $+\mathrm{N}_{\text {dat }}+$ gelicost & 26 \\
\hline \multicolumn{3}{|c|}{ 2.1.1.1. open simile: } \\
\hline a) & $\mathrm{N} /$ Pron $+\mathrm{N}_{\mathrm{dat}}+$ gelicost & 6 \\
\hline b) & $\mathrm{N}+\mathrm{N}_{\text {dat }}+$ gelicost $+\mathrm{NP}($ Adj $+\mathrm{N}+$ clause $)$ & 1 \\
\hline \multicolumn{3}{|c|}{ 2.1.1.2. closed simile: } \\
\hline a) & $\mathrm{N}+\mathbf{A d j}+\mathrm{N}_{\text {dat }}+$ gelicost + clause & 1 \\
\hline b) & $\mathrm{N}+\mathbf{V} / \mathbf{V P}+\mathrm{N}_{\text {dat }}+$ gelicost & 9 \\
\hline c) & clause $+\mathrm{N}+\mathrm{N}_{\mathrm{dat}}+$ gelicost & 1 \\
\hline d) & $\mathrm{N}+\mathrm{N}_{\mathrm{dat} / \text { Pron }_{\mathrm{dat}}+\text { gelicost }+ \text { clause }}$ & 8 \\
\hline 2.1 .2$. & $\mathrm{N}_{\text {dat }}+$ gelicost + clause $/ N_{\text {nom }} P$ & 2 \\
\hline 2.2 & \multicolumn{2}{|c|}{$\begin{array}{l}\text { Old English similes with the gelicost component employing a noun in a nominative } \\
\text { case }\end{array}$} \\
\hline 2.2 .1 & $\mathrm{~N}+\mathbf{A d j}+$ onlicost $+\mathrm{N}_{\text {nom }} \mathrm{P}\left(\mathrm{N}_{\text {nom }}+\right.$ clause $)$ & 2 \\
\hline
\end{tabular}




\begin{tabular}{|l|l|}
\hline Type & Amount \\
\hline $2.2 .2 . \quad \mathrm{N}+\mathbf{V}+$ gelicost + clause & $\mathbf{1}$ \\
\hline Total & $\mathbf{3 1}$ \\
\hline
\end{tabular}

The figures show a strong tendency to start simile with a tenor preceding a vehicle, expressed by a masculine or a neuter noun in the dative case, followed by the gelicost component. Since this positioning is true for the majority of the similes in question, it can be called a typical syntactic pattern of the Old English simile with the gelicost component. The employment of the nominative case vehicle was less frequent ( 3 cases out of 31 ) though representing $10 \%$ of the total sampling, it can be said to have been an alternative to the dative case simile structure being its grammatical synonym. A commonly shared salient feature, if explicitly marked, is usually placed either between the tenor and the vehicle or in the clause following the whole construction. It is typically expressed by verbs, verb phrases or clauses and less frequently by adjectives.

An interesting feature of these types of similes is that only masculine or neuter nouns were used as vehicles; there were no cases of feminine-vehicle nouns. On the one hand, this could be a coincidence, but on the other hand this fact gives the grounds to assume that the gender of the vehicle might have influenced the choice of the comparison marker. Though for the time being such an assumption can only be a subject of speculation until further investigations of Old English similes have been conducted.

The chronological aspect can hardly be considered an exact moment of the "birth" or "death" of certain structural types, though it shows the tendency to be widely and constantly or, for some reasons, sporadically used. The chronological appearance of the constructions in question is presented in Table 2. Since the exact date of creation is unknown and there is still much speculation concerning many of the manuscripts, the data, the data are based on the information provided by the York-Toronto-Helsinki Parsed Corpus.

As we can see from the table, the basic Old English simile construction (N / Pron $+\mathrm{N}_{\text {dat }}+$ gelicost $)$ is typical for the whole period: Having appeared in the $6^{\text {th }}$ century, it was permanently used with different variations of salient feature expression up to the Norman conquest. Solitary instances of other structural types can be logically explained. The second structural type was first used in the $7^{\text {th }}$ century "Beowulf" and then, later, in the $9^{\text {th }}$ century "Andreas" for which there are two possible reasons: 1) it could be another proof of the hypothesis that the author of "Andreas" read the manuscript of "Beowulf" and might have employed the construction used in it (this subject is still a matter of speculations); 2) the possible reason for deviation from a typical syntactic pattern in these cases can be accounted for by the demands of prosody since both of them are poems. As for the single similes of the third and fourth types, since both works were translations from Latin, I can presume that the structure of the original sentence must have 
influenced the translator's wording choice in the target language with Latin being more developed and, correspondingly, influential at the time.

Table 2. The chronological appearance of the Old English simile of equality containing a gelicost component

\begin{tabular}{|c|c|c|c|c|c|c|c|c|}
\hline Structural type $\quad$ Century & 青 & $\stackrel{F}{I}$ & $\underset{\infty}{1}$ & స్ & 平 & $\stackrel{F}{\stackrel{F}{\Xi}}$ & 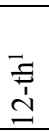 & 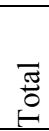 \\
\hline 2.1.N / Pron $+\mathrm{N}_{\mathrm{dat}}+$ gelicost & 1 & 5 & 1 & 6 & 7 & 3 & 3 & 26 \\
\hline 2.1.2. $\mathrm{N}_{\mathrm{dat}}+$ gelicost + clause / $\mathbf{N}_{\text {nom }} \mathbf{P}$ & & 1 & & 1 & & & & 2 \\
\hline 2.2.1. $\mathrm{N}+\mathbf{A d j}+$ onlicost $+\mathrm{N}_{\text {nom }} \mathrm{P}\left(\mathrm{N}_{\mathrm{nom}}+\right.$ clause $)$ & & & & 2 & & & & 2 \\
\hline 2.2.2. $\mathrm{N}+\mathbf{V}+$ gelicost + clause & & & & & 1 & & & 1 \\
\hline Total & 1 & 6 & 1 & 9 & 8 & 3 & 3 & 31 \\
\hline
\end{tabular}

In terms of explicitness of the salient feature, Old English similes in question can be either open or closed as M. C. Beardsley defined them. Of the thirty one Old English similes of equality with the superlative degree of lice 24 are closed while the rest 7 are open; such a big amount of closed similes clearly contributes to the elimination of complexity in the worldview of Anglo-Saxons.

\section{The semantic characteristics of the Old English simile with the gelicost component}

The semantic analysis of similes is quite a challenge judging from the existence of different approaches to their classification. Most linguists group similes according to a) the vehicles, organizing the latter into thematic groups of nature, artefacts, anthroponyms, animals etc. (Gergel 2008; Riabikina 2006; Denisova 2009; Shie 2007; Moon 2008; Tomita 2008); b) the tenors and the vehicles, organising both into thematic groups (Chernousova 2014; Kondakova 2005; Kazakov 2005; Kryvenko 2006; Chudyk 2012; Yudina 2012); c) the general meaning of simile referring to a certain sphere of extralinguistic reality, singling out such groups as appearance, action, character etc. (Talko 2009; Shevchenko 2003); d) the lexical meaning of a tenor or vehicle (Rumiantseva (2007)); e) the positive/negative connotation of the ground (Veale 2009; Hao 2009). The abovementioned classifications were worked out for the empirical data of modern languages; to the best knowledge of the author, there is no semantic classification of the Old English similes.

Though the $12^{\text {th }}$ century is chronologically a Middle English period, the manuscripts in questions (Paris Psalter) are considered to have been written in the Old English according to the data of University of Leicester (http://www.le.ac.uk/english/em1060to1220/catalogue/IndexFrench.htm) 
The semantic analysis of similes should definitely reflect the peculiarities of all three semantic constituents which are the tenor, the vehicle and the ground. The fourth one, a comparison marker, is not crucial in this case being more of a structural element. The most important question is which simile element should be taken as the starting point of semantic classification. How should one prioritize the tenor and the vehicle; or should it be the ground the ground around which the whole classification should be centered?? The author considers all three elements to be important, interdependent and interconnected, because the choice of the vehicle depends on the salient feature, of which it should be a typical representative. The presence of the salient feature depends on the presence of topic (if there is no topic, there can be no salient feature). Finally, the distinctiveness and clarity of the topic depends on the choice of the vehicle (the more standard and typical the vehicle-bearer of the salient feature is, the more clear and distinct is the information about the topic).

I suggest that the semantic classification of simile should be done on two levels: from a macro level perspective and a micro level perspective; with neither being better than the other, but the combination of which being able to reveal a more consistent and complex picture concerning the analysed material. The macro level perspective will consider the full panorama of similes in question from a more abstract and philosophical standpoint based on certain principles, while a micro level perspective will focus on small scale combinations and the manifestation of particular tenor-ground-vehicle models. The macro level paradigm naturally incorporates several micro-level ones, but since the amount of the analysed units is rather sparse which will inevitably lead to numerous but scarcely filled subgroups, the two subgroups will be presented separately for the sake of convenience.

\subsection{Macro level paradigm of the Old English Simile with the gelicost component.}

Since the tenor and the vehicle are of equal semantic value and are the two core elements of simile, the taxonomy of Old English similes in their lexico-semantic scope can be based on two principles: the principle of centric quality represented by the tenor and the principle of morphing represented by the vehicle. The reason to single out the principle of centric quality is the fact that while creating a simile the speaker tells about a referent denoted by the tenor by means of resorting to the image of the referent denoted by the vehicle but not vice versa: The aim is to specify, centre around the tenor, not the vehicle. Thus, comparing the unique colour of the bird with the one of the peacock grown with joys (10), the speaker narrates about a Phoenix, not a peacock; the author's aim is to specifically account for the exclusively particular plumage of the Phoenix, for which reason he uses the image of a peacock as nothing but the means to create an eloquent picture of the former. The same is true for any other example, for instance, when the author compares the conduct of the fourteen successors with the one of hungry lions (11), 
he does not narrate about the predators. He focuses reader's attention on the extremely savage behaviour of people while the lions are just an auxiliary image helping to vividly describe the ferocious and uncivilized manner of humans. Every simile is narration about the tenor, therefore, attention is focused on the tenor, it is centred around the tenor, and the aim of the simile is the precise representation of the tenor. It allows us to speak about the principle of centric quality.

On the other hand, being the means of explanation, specification, description etc. of the tenor, the vehicle is not less semantically important than the tenor. It is the etalon of the quality that it explains, specifies, describes etc. It is the vehicle with its salient feature that reveals widely-held ideas and stereotypes of the community, that gives us the grounds to analyse similes focusing on the nature of the vehicle. The tenor is almost made equivalent to the vehicle, it is almost "turned into" the vehicle. This is why the principle of morphing comes forward. In the examples, mentioned above, (10) and (11), the Phoenix and the fourteen successors look like, remind, and are similar to the peacock and lions respectively, the authors juxtapose the two as if turning the former into the latter, making both tenors zoomorphic. To achieve the goal of the centric-morphic approach to the semantic analysis of similes, covering the whole scope of the sampled examples, the need to fill the terminology gap arises, existing due to the lack of complex universal approach to their classification. For this reason, the policy of terminology-coining has been based on the analogy with existing terms describing similes and metaphors in specialized literature, the most frequent being anthropocentric/theocentric and anthropomorphic/theomorphic. Thus, the simile (10) is zoocentric and zoomorphic falling within the scope of the similes of characteristics of appearance, while the simile (11) is anthropocentric and zoomorphic, falling within the scope of similes of behaviour. The type of the scope of similes depends on the juxtaposed elements of extralinguistic reality.

The whole bulk of the sampled similes falls within the three scopes: 1) similes juxtaposing actions/states; 2) similes juxtaposing things/people / animals/phenomena; 3) similes juxtaposing situations.

\subsubsection{The Old English similes with the gelicost component juxtaposing actions / states}

These similes can be organized into 5 types with the further subdivision: 1) anthropocentric similes; 2) artefactocentric similes, comprising artefactocentric-zoomorphic and artefactocentric-ecomorphic ones; 3) ecocentricecomorphic; 4) zoocentric-creaturemorphic; 5) theocentric similes, comprising theocentric-ecomorphic and theocentric-zoomorphic ones.

\subsubsection{Antropocentric similes juxtaposing actions/states}

Such similes are aimed at shaping a precise and clear understanding of a certain action or/and its characteristics by means of two notions juxtaposition based on the similar action they can both perform. The common salient feature in this case can be the action itself or its intensity, the extent of the action or the way it is done 
so it can be either explicitly or implicitly expressed by a verb or a combination of a verb and an adverb. Among them the following subtypes can be singled out:

a) anthropocentric-ecomorphic similes compare the characteristics of the actions of some inalienable parts of a person to the actions of certain natural phenomena. They highlight the intensity of the action in which case the vehicle could be substituted with the words "very intensely" (9). In this example from the 9-th century "Andreas" the author compares the flood of blood to rain clearly stressing the intensity of the flow of blood. Another example of this kind (2) is taken from "Beowulf" where the light of Grendel's eyes is compared to the dreadful light of a flame. In both cases blood and eyes, which are inalienable parts of a person, are compared to nature elements (water and fire) both being occasionally raging, intense and uncontrollable for people cannot control their blood flow or eyes shining just like they cannot control nature. Simile used for the description of Grendel is considered to be anthropocentric in this paper since the author supports those scholars' opinions (Heaney 1999; Tolkien 2014) according to which Grendel's nature was more of a human than beast, being the ancestor of biblical Cain and the son of a woman.

b) Anthropocentric-zoomorphic similes compare people's actions with those of animals to to represent the positive and negative aspects of human nature

To describe favourable deeds the images of harmless animals are employed (12) while the images of predators are used to highlight unworthy human actions (13):

....miht somod sibiab sawla mid lice,fagre gefrcetwed, fugle gelicast.

'. w. will journey souls together with body, handsomely adorned, to a bird most like,

in eadwelum cepelum stencum...

with noble perfumes...'

The simile taken from the 9-th century "Phoenix" describes a good Christian being able to get into paradise as easily and naturally as a bird flying while in another example taken from the 11-th century "Sermo ad Anglos" undeserving and shameful behaviour is described in a comparison of men to dogs:

...\& ane cwenan gemcenum ceape bicgað gemone, \& wið pa ane fylpe

'.. and buying a woman in one joined purchase for common use, and practicing filth upon her adreogad, an after anum \& aelc cefter oðrum, hundum gelicost pe for fylpe ne scrifað, one after another and each man after the other to dogs most like who have no care for filth...'

c) Anthropocentric-artefactomorphic similes juxtapose a person's soul or spirit with a wheel both spinning around to depict the movement of the 
soul or spirit after death thus explaining a complicated and abstract idea with a concrete and comprehendible notion:

Swa deð monnes saul, hweole gelicost; hwcerfð ymbe hy selfe.

'So dead man's soul, to a wheel most like; spins around itself.'

d) Anthropocentric-creaturemorphic simile was employed to characterise the state of a sleeping person by comparing it to death. Since death is typical not only for people but for all living-beings the example taken from the 9-th century "Solomon and Saturn" has been classified as creaturemorphic:

(15)

....sorg bið swarost byrðen, slcep bið deaðe gelicost.

'...sorrow is the heaviest burden, sleep is most like death'

\subsubsection{Artefactocentric similes juxtaposing action / state / process}

Such similes are aimed at shaping a precise and clear understanding of the action or a property attributed to the object by explaining of what the object is capable. Four sampled similes of the kind can be divided into:

a) artefactocentric-ecomorphic type comparing weapon to ice or wax both being capable of melting (8).

b) artefactocentric-zoomorphic type comparing a ship to a bird both gliding over the water:

(16)

Is pes bat ful scrid, fcereð famigheals, fugole gelicost glideð on geofone.

'The ship, with a foamy neck, to a bird most like went over the sea'

All four examples in question were found in "Beowulf" and "Andreas". The authors resort to simile in these cases not so much to describe the objects but to highlight the attending circumstances of the actions. In (16) gliding over the sea speaks about the calm sea allowing for a smooth, quiet and continuous motion while a melting weapon in (8) testifies that there was some kind of a miracle.

\subsubsection{Ecocentric-ecomorphic simile juxtaposing action/state/process}

The only simile of this kind was employed in Phoenix to emphasise the transience of existence and the omnipotence of God (6).

\subsubsection{Zoocentric-creaturemorphic simile juxtaposing action/state/process}

This type of simile was found in the 11-th century "Saint Oswald" comparing a horse to a mad creature to eloquently describe the movements of a sick animal in agony: 
(17)

...pa wearð his hors gesicclod, and sona pær feol, wealwigende geond

'...when his horse became sick, and immediately fell there, rolling over the

ða eorðan wodum gelicost

earth, to a mad creature most like.

\subsubsection{Theocentric similes juxtaposing action/state/process}

They help to create a didactic atmosphere teaching people to differentiate between good and bad. They can be:

a) theocentric-ecomorphic simile as in "Christ and Satan" comparing Satan's words to poison since both can easily be flown in a stream (3).

b) theocentric-zoomorphic similes allow to reveal the nature or mood of a deity that can be either positive (employing the image of harmless animals) or negative (resorting to the image of predators):

(18)

... and se hlaford ne scrifð, ðе ðœm here waldeð, freonde ne feonde, feore

'.. and the lord does not care, who the army rules over, whether friend,

ne cehtum, ac he reðigmod roest on gehwilcne, wedehunde wuhta gelicost; $;.$.

or foe, life or possessions, but savage in mind he assaults/rushes onto all, $\underline{\text { like a mad dog...' }}$

\subsubsection{The Old English similes with the gelicost component juxtaposing things/people/animals/phenomena}

Such similes can be organized into 5 types with the further semantic subdivision: 1) anthropocentric-artefactomorphing; 2) ecocentric either ecomorphic or creaturemorphing; 3) theocentric being ecomorphic or situational; 4) artefactocentric-situational; 5) zoocentric either artefactomorphing or zoomorphic. These similes usually highlight a certain property or characteristic of juxtaposed notions where the ground can be explicitly or implicitly expressed by an adjective or verb the lexical meaning of which shows some property (e. g. to glitter).

\subsubsection{Antropocentric similes juxtaposing things/people/animals/phenomena}

They aim at pointing out a physical or psychological feature of a human, potentially leading to some consequences, by comparing a person or his/her unalienable part to a certain artefact having a typical easily decodable feature:

Swa hit awriten is on Salomonnes cwidum ðatte se mon se ðe ne mag

'As it is written in the proverbs of Solomon, the man who cannot hold

his tungan gehealdan sie gelicost openre byrig, ðcere ðe mid nane wealle ne bið ymbworht.

his tongue is most like an unprotected city, with no surrounding walls.' 
In the example taken from the 9-th century "Pastoral care" the image of an unprotected city is not much of a characteristic itself but a means to highlight the reason why a talkative person can easily be subjected to risk and danger where the simile would be the answer to this question - because he/she is unprotected and vulnerable. In other words, talkativeness may cause danger. All three sampled similes of this type can be said to function like a warning against something unpleasant.

\subsubsection{Ecocentric similes juxtaposing things/people/animals/phenomena}

These similes describe physical features of a natural phenomenon or a substance without any implicature whatsoever. They are represented by two examples:

a) Ecocentric-ecomorphic simile comparing ice to a precious stone in the 9th century "Rune Poem":

//is // byp oferceald, ungemetum slidor, glisnap glceshluttur, gimmum gelicust, ...

'(Ice) is very cold, and immeasurably slippery, glitters, clear as glass, to a precious stone most like...'

b) Ecocentric-creaturemorphic simile comparing sardonyx to blood was found in the 10-th century "Lapidary" to describe its colour:

Fyfta sardonix is haten se is blode licost.

'Sardonix is hot, to blood most like.'

\subsubsection{Theocentric similes juxtaposing things/people/animals/phenomena}

Such similes serve to describe a deity or a related notion highlighting its appealing features. The authors resort to the image of a nature phenomenon to stir the readers' imagination and create positive sensations. Theocentric-ecomorphic simile compares an angel to a breeze (5).

\subsubsection{Zoocentric similes juxtaposing things/people/animals/phenomena}

Two similes of this kind, found in "Phoenix," were designed to clearly and understandably describe a mythic bird's appearance. For this purpose, both an artefact and other images of animals were employed:

a) Zoocentric-artefactomorphic simile compares the phoenix's eyes to a gem in the crown (4)

b) Zoocentric-zoomorphic simile employs the image of the closest animal to the unique bird (10). 


\subsubsection{The Old English similes with the gelicost component juxtaposing situations}

These similes can be organized into 2 types: 1) theocentric; 2) artefactocentric. The peculiarity of similes juxtaposing situations is that both the tenor and the vehicle in this case represent a situation, not a separate participant of it. They usually exemplify extended similes where the tenor and the vehicle are expressed by complex or compound sentences comparing a current and a hypothetical situation:

\subsubsection{Theocentric simile with the gelicost component juxtaposing situations} It employs a hypothetical situation as an explanation, the reason of the result expressed by abstract notions of mercy and concord:

...ic wille eac forp gesecgan hwelc mildsung \& hwelc gepwcernes sippan woes sippan

'... I intend also to set forth what mercy and what concord there has been since the advent

$\leq$ se $>$ cristendom woes, gelicost poem pe monna heortan awende wurden, for pon pe pa cerran of Christianity, most like as though the hearts of men had become changed, because the ping agoldene waron.

previous things had been paid for.'

3.1.3.2. Artefactocentric simile with the gelicost component juxtaposing situations This simile marks the situation centered around a broken silver dish. The absence of silver dishes at a feast is referred to as a wonder:

Gif hit swa is swa ðu sagst, ðonne is paet egeslicre ðonne cenig oðer broga, \& is endeleas

'If it is as you say, then it is more horrible than any other terror, and it is an endless wundor, ðcem gelicost ðe on sumes cyninges hirede sien gyldenu fatu \& selfrenu forsewen, wonder,most like golden and silver vessels being scorned in the household of a certain king, \& treowenu mon weorðige. and wooden ones being valued.'

To emphasise the unusual characteristic of the happening the author of the 9-th century "Boethius" creates an unbelievable and unreal situation for the time, to which only a wonder can be equated, as a most suitable means to explain the impossibility of the case.

The semantic characteristics of the Old English similes with the gelicost component according to the centric principle of classification are shown in Table 3: 
Table 3. The macro paradigm of the semantic characteristics of the Old English similes of equality with the gelicost component.

\begin{tabular}{|c|c|c|c|c|}
\hline $\begin{array}{l}\text { Type of simile } \\
\text { (centric principle) }\end{array}$ & $\begin{array}{c}\text { Similes } \\
\text { juxtaposing } \\
\text { actions / } \\
\text { states }\end{array}$ & $\begin{array}{c}\text { Similes } \\
\text { juxtaposing } \\
\text { things / } \\
\text { people / } \\
\text { animals / } \\
\text { phenomena }\end{array}$ & $\begin{array}{c}\text { Similes } \\
\text { juxtaposing } \\
\text { situations }\end{array}$ & Total \\
\hline \multicolumn{5}{|l|}{ 1. Anthropocentric } \\
\hline 1.1. Anthropocentric-ecomorphic & 3 & - & - & 3 \\
\hline 1.2. Anthropocentric-zoomorphic & 4 & - & - & 4 \\
\hline 1.3. Anthropocentric-artefactomorphic & 2 & 3 & - & 5 \\
\hline 1.4. Anthropocentric-creaturemorphic & 1 & - & - & 1 \\
\hline \multicolumn{5}{|l|}{ 2. Artefactocentric } \\
\hline 2.1. Artefactocentric-ecomorphic & 2 & - & - & 2 \\
\hline 2.2. Artefactocentric-zoomorphic & 2 & - & - & 2 \\
\hline 2.3. Artefactocentric-situational & - & - & 1 & 1 \\
\hline \multicolumn{5}{|l|}{ 3. Ecocentric } \\
\hline 3.1. Ecocentric-ecomorphic & 1 & 1 & - & 2 \\
\hline 3.2. Ecocentric-creaturemorphic & - & 1 & - & $\mathbf{1}$ \\
\hline \multicolumn{5}{|l|}{ 4. Zoocentric } \\
\hline 4.1. Zoocentric-creaturemorphic & 1 & - & - & 1 \\
\hline 4.2. Zoocentric-artefactomorphic & - & 1 & - & $\mathbf{1}$ \\
\hline 4.3. Zoocentric-zoomorphic & - & 1 & - & 1 \\
\hline \multicolumn{5}{|l|}{ 5. Theocentric } \\
\hline 5.1. Theocentric-ecomorphic & 2 & 1 & - & 3 \\
\hline 5.2. Theocentric-zoomorphic & 3 & - & - & 3 \\
\hline 5.3. Theocentric-situational & - & - & 1 & 1 \\
\hline Total & 21 & 8 & 2 & 31 \\
\hline
\end{tabular}

Notwithstanding the fact that a thousand-year-period separates us from Anglo Saxons the similes under consideration are not difficult to interpret, even the open ones. The context provides all the necessary information, making the message relatively easy to grasp.

Similes under analysis represent almost everything people deal with in life: nature, fauna, deities, artefacts, and life situations, except for flora. As it is seen from the statistics provided in Table 3, the most frequent similes in question are anthropocentric ones especially those focusing on the actions that might stem from the fact that Anglo-Saxon society focused on people and their deeds to a greater extent than on any other aspect of life. Nature and animals, on the other hand, are represented more often (17 out of 31 cases) in the morphic part of the similes under analysis being the etalons of some salient features rather than the focus of peoples' attention. A relatively little number of theocentric similes, however, can be misleading and should not imply that Anglo-Saxon society was mainly anthropocentric with, strangely for a medieval community, deficient theological tradition. Out of 31 sampled similes only half of them concentrated on some 
material wealth. The other half concerned Christian spiritual issues, though employing non-theological images, for example in (people-sheep, man-dogs, weapon-wax) whose implicatures are purely theological. Comparing people to dogs practicing filth or a sheep clearly draws the distinction between a good Christian and a bad one. Also, through the description of the ability to melt weapons the omnipotence of God is highlighted. From this we can conclude that simile is a very powerful communicative tool capable of conveying implicit ideas not reflected in the lexical meaning of a tenor and a vehicle. The fact that the number of anthropocentric similes surpasses the number of theocentric ones can be explained by a didactic character of Anglo-Saxon texts which were more aimed at shaping a conscientious Christian rather than describing God.

\subsection{Micro level paradigm of the Old English Simile with the gelicost component.}

The initial division of similes in question according to the centric-morphic principle can be specified by further classification based on correlation of particular referents, employed to form a simile, united by a motivational feature serving as a ground of the simile. This correlation could be represented by the semantic model of simile (Figure 1) with the arrow showing the direction of similarity, on the basis of which a more concrete classification can be built.

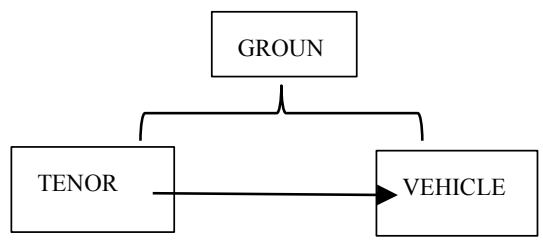

Figure 1. The semantic model of simile.

Being a commonly shared feature of the tenor and the vehicle, the ground plays a unifying role being the motive to juxtapose those two referents in the first place, therefore, the generalized scope of referents, denoted by it, might be a unifying element of the generalized scopes of referents, denoted by the tenor and the vehicle organizing them into a certain number of thematic groups. Both the tenor and the vehicle are semantically equally important, representing different aspects of speakers' viewpoints: the tenor is the phenomenon people talk about, thus showing us the priorities and subjects of their interest, while the vehicle is a phenomenon with the help of which people can eligibly specify their priorities and subjects of interest, thus, revealing to us the paradigm of images reflecting the collective consciousness. Only a particular combination of the three elements can reveal the semantics of simile, both explicit and implicit.

Whatever the aim and implicature of simile, it operates through juxtaposition of notions that, being combined to describe behaviour, functioning, appearance 
etc., pass certain cultural codes representing ethnic identity reflecting certain mental and emotional features. These codes can change over time or they can stay in cultural memory: The comparison of people with sheep would not sound strange to a modern ear, but the comparison of a talkative person with a city without walls would be quite unexpected and puzzling nowadays. Thus, the classification based on centrism and morphism principle showing thematic priorities of Anglo-Saxon poetics can further be specified by the list of the motivational features, being the basis of the ground, allowing to juxtapose the tenors and the vehicles of the similes in question.

The whole paradigm of the grounds of the similes under analysis represented by concrete tenor-vehicle correlations is the following:

\subsubsection{The action itself, the way it is performed, the extent to which it is performed:}

3.2.1.1. The same functioning (7 out of 31 ):

a) light $\rightarrow$ flame with its power to shine;

b) deity $\rightarrow$ unicorn with its pure nature;

c) deity $\rightarrow$ eagle with the renovation and salvation it brings;

d) blood $\rightarrow$ rain with its heavy streams;

e) sword $\rightarrow$ ice with its ability to melt;

f) weapon $\rightarrow$ wax with its ability to melt;

g) land $\rightarrow$ wind with its ability to disappear;

3.2.1.2. the same ability (7 out of 31 ):

a) ship $\rightarrow$ bird (twice) with its ability to float;

b) body and soul $\rightarrow$ bird with its ability to fly;

c) dead man's soul $\rightarrow$ wheel (twice) with its property to turn around;

d) words $\rightarrow$ poison with its ability to damage;

e) deity $\rightarrow$ water with its ability to spread filling everything;

\subsubsection{3. the same behaviour (5 out of 31 ):}

a) men $\rightarrow$ dogs mating with numerous subjects;

b) people $\rightarrow$ sheep being meek and obedient;

c) people $\rightarrow$ hungry lion cubs being aggressive and merciless;

d) horse $\rightarrow$ mad creature affected by a disease, unable to control its body;

e) deity $\rightarrow$ mad dog being angry;

\subsection{2. the same state ( 2 out of 31 ):}

a) $\quad$ man $\rightarrow$ stone with its motionlessness;

b) sleep $\rightarrow$ death with its passiveness and inactivity; 


\subsection{3. the same physical characteristics (6 out of 31);}

\subsection{4. appearance:}

a) bird $\rightarrow$ peacock (its look);

b) eyes $\rightarrow$ jewel with its brightness;

c) precious stone $\rightarrow$ blood (its colour);

\subsection{5. property:}

d) nail $\rightarrow$ steel being very hard;

e) ice $\rightarrow$ jewel being shiny;

f) angel $\rightarrow$ breeze being cool and pleasant;

3.2.6. the same psychological characteristics ( 1 out of 31):

a) talkative person $\rightarrow$ unprotected city being vulnerable;

\subsection{7. the same characteristics of deeds ( 1 out of 31 ):}

a) $\sin \rightarrow$ weapon being very sharp and capable of killing;

\subsection{8. the same situations ( 2 out of 31 ):}

a) concord among people $\rightarrow$ change of hearts due to debt payment;

b) absence of silver dishes at a feast $\rightarrow$ preposterous kingdom;

As seen in the paradigm, it is the description of functioning and abilities of certain referents that necessitated the use of simile under consideration most frequently (14 out of 31), employing the vehicles from different scopes of reality. The behaviour, though, is always described by means of resorting to the stereotypical animals' behaviour. The thematic variety of the Old English similes in question speak in favour of the fact that Anglo-Saxons in their literary tradition concentrated on the outer manifestations of the properties of deities or people while the inner world of a person was not the focus of their attention. Most sampled similes contain concrete images as vehicles from which we can conclude that simile was not only a matter of poetics but could serve as a means to lucidly present complex ideas.

Having established the regularities of certain tenor-vehicle correlations it is possible to find out typical simile collocations in the Old English; regular combinations of vehicle with the salient feature it represents prompt us to consider the existence of some widely held ideas concerning different aspects of AngloSaxons' life. The material shows that two tenors (ship and floater) were used with the same vehicle (bird) on the same ground (going over the sea) as well as one and the same ground (entire melting) was used as a commonly shared feature of a weapon, ice and wax. The repetition of the vehicle as well as the ground used twice may well be considered a regularity. Thus, we can speak of an idiomatic character of the Old English phrase "to go over the sea like a bird" or we can 
assume that if something disappeared an Anglo-Saxon speaker would figuratively say that "it melted like ice or wax".

\section{Conclusion}

Our investigation of the Old English simile of equality with the gelicost component has led to several conclusions: 1) structurally they represent the combination of a masculine or a neuter noun in the dative case (vehicle of a simile) with the gelicost component following a noun or a pronoun (tenor of a simile) with sometimes verbalized, positionally independent ground of a simile. Less frequently (in $10 \%$ of cases), when the vehicle-noun follows gelicost, the nominative case of the noun is employed, that is considered to be the loan translation from Latin; 2) the similes in question were productive throughout the whole Old English period; 3) from the macro-level perspective the majority of Old English similes with the gelicost component are anthropocentric and theocentric ones; from the micro-level perspective the majority of similes in question describe functioning or abilities of referents; 4) the repetitive tenorvehicle combinations can speak of the idiomatic character of certain Old English similes.

\section{References}

Amodio, Mark. 2014. The Anglo-Saxon Literature Handbook. Hoboken: Wiley Blackwell.

Anderson, Orval. 1951. Once More: the OE Simile. Philological Papers 8. 1-12.

Baker, Peter. 2012. Introduction to Old English. Hoboken: Wiley Blackwell.

Beardsley, Monroe. 1981. Aesthetics: problems in the philosophy of criticism. Indianapolis: Hackett Publishing.

Cavill, Paul. 1999. Maxims in Old English poetry. Cambridge: D.S. Brewer.

Chernousova Olga. 2014. Funkcionirovanie obraznyx sravnenij v regionalnoj xudozhestvennoj proze i ustnoj rechi dialektonositelej. Avtoref. dis. na soiskanie nauch. stepeni kand. filolog. nauk : spec. 10.02.01 „russkij yazyk”. Volgograd.

Chudyk, Dorota. 2012. Rosyjskie i polskie konstrukcje porównawcze z przymiotnikami nazywającymi barwę zieloną (semantyka i struktura). Zeszyty naukowe uniwersytetu rzeszowskiego. Seria filologiczna: Glottodydaktyka 4 : Zeszyt 76. 9-20.

Dawes, Gregory. 1998. The body in question: metaphor and meaning in the interpretation of Ephesians 5:21-33. Leiden: Brill.

Denisova Galina. 2009. Kognitivnyj mexanizm sravneniya v nemeckom yazyke. Avtoref. dis. na soiskanie nauch. stepeni doktora filolog. nauk : spec. 10.02.04 ,germanskie yazyki”. Samara.

Fisher, Olga. 1992. Syntax. In Norman Blake (ed), The Cambridge History of the English Language, vol. II: 1066-1476, 207-407. Cambridge and New York: Cambridge University Press.

Gergel, Aleksandr. 2014. Obraznye paradigmy sravnenij, xarakterizuyushhix muzhchinu $i$ zhenshinu (na materiale sovremennoj angloyazychnoj zhenskoj prozy). Avtoref. dis. na soiskanie nauch. stepeni kand. filolog. nauk : spec. 10.02.04 „Germanskie yazyki”. Ufa.

Gergel, Remus. 2008. Comparatives and Inversion in English: A (Necessarily) Diachronic Account. U. Penn Working Papers in Linguistics., vol. 14.1. [Online]. 177-190. Available from: 
https://repository.upenn.edu/cgi/viewcontent.cgi?article=1030\&context=pwpl [Accessed: 30th Oktober 2018].

Heaney, Seamus. 1999. Beowulf: A New Verse Translation. London: Faber.

Kazakov Andrei. 2005. Obraznye sredstva i paradigmaticheskie ryady obrazov s nazvaniyami chastej tela v sovremennom anglijskom yazyke. Avtoref. dis. na soiskanie nauch. stepeni kand. filolog. nauk : spec. 10.02.04, ,germanskie yazyki”. Moskva.

Kondakova Irina. 2005. Obraznye sredstva, soderzhashhie toponimy v anglijskom yazyke : avtoref. dis. na soiskanie nauch. stepeni kand. filolog. nauk : spec. 10.02.04 ,germanskie yazyki”. Moskva.

Kryvenko Ganna. 2006. Zoosemizmi v anglijskij ta ukraïnskij movax: semantiko-kognitivnij i funkcionalno-pragmatichnij aspekti. Avtoref. dis. na zdobuttya nauk. stupenya kand. filolog. nauk : spec. 10.02.17 ,porivnyalno-istorichne i tipologichne movoznavstvo”. Kï̈v.

Margolis, Joseph. 1957. Notes on the Logic of Simile, Metaphor and Analogy. American Speech, vol. 32, No. 3, 186-189. Durham: Duke University Press.

McLaughlin, John. 1983. Old English Syntax. Max Niemeyer Verlag: Tübingen.

Merritt, Carlton C. 2013. Descriptive Syntax of the Old English Charters. Berlin: De Gruyter.

Mitchel, Bruce. 1985. Old English Syntax. Oxford: Clarendon Press.

Moon, Rosamund. 2008. Conventionalized as-similes in English: a problem case. International Journal of Corpus Linguistics. 3-37. Amsterdam: John Benjamins.

Nevanlinna, Saara. 1993. The Structure of Middle English similes of equality. Early English in the Computer Age: Explorations Through the Helsinki Corpus. 139-170. Berlin and New York: Mouton de Gruyter. Available from: publication/228509486_Support_structure_for_linguistic_ creativity_A_computational_analysis_of_creative_irony_in_similes.

[Accessed $18^{\text {th }}$ October 2018].

Riabikina Nataliia. 2006. Poetika ocenochnyx znachenij v proizvedeniyax i. a. Bunina. Avtoref. dis. na soiskanie nauch. stepeni kand. filolog. nauk : spec. 10.02.01 „russkij yazyk”. Moskva.

Rumiantseva Marina. 2007. Tipologicheskie osobennosti komparativnyx konstrukcij (na materiale russkogo i nemeckogo yazykov). Avtoref. dis. na soiskanie nauch. stepeni kand. filolog. nauk : spec. 10.02.20 „sravnitelno-istoricheskoe, sopostavitelnoe i tipologicheskoe zykoznanie”. Chelyabinsk.

Shevchenko Anna. 2003. Sravnenie kak komponent idiostilya pisatelya-bilingva v. nabokova (na materiale russko- i angloyazychnyx proizvedenij avtora). Avtoref. dis. na soiskanie nauch. stepeni kand. filolog. nauk : spec. 10.02.19 „teoriya yazyka”. Saratov.

Shie, Jian-Shiung. 2007. The Semiotic Structure and Semantic Composition of English Frozen Similes. Journal of Humanities and Social Sciences, vol. 3, No. 1, 57-68.

Stodnick, Jacqueline, Trilling, Renee R. 2012. A Handbook of Anglo-Saxon Studies. Hoboken: Wiley Blackwell.

Talko Svitlana. 2009. Lingvoaksiologichna semantika antropocentrichnix metafor ta porivnyan v ukraïnskij i anglijskij movax. Avtoref. dis. na zdobuttya nauk. stupenya kand. filolog. nauk : spec. 10.02.17 „porivnyalno-istorichne i tipologichne movoznavstvo”. Kiïv.

Tolkien, John. 2014. Beowulf: A Translation and Commentary, together with Sellic Spell. New York: HarperCollins Publishers.

Tomita, Saoko. 2008. Similes in Oliver Twist: Humanisation and Dehumanisation. ERA, New Series, vol.25. № 1\&2, 25-42.

Tyler, Elizabeth. 2006. Old English Poetics: The Aesthetics of the Familiar in Anglo-Saxon England. York: York Medieval Press.

Veale, Tony, Hao, Yanfen. 2009. Support Structures for Linguistic Creativity: A Computational Analysis of Creative Irony in Similes. [Online] Available from https://www.researchgate.net/

Walker, Marilyn A. 2016. Automatically Inferring Implicit Properties in Similes. Proceedings of NAACL-HLT. [Online]. 1223-1232. Available from: http://www.aclweb.org/anthology/. [Accessed: 30th October 2018]. 
Yudina Yuliia. 2012. Modeli obrazov sravnenij v yazyke russkoj xudozhestvennoj literatury konca xx - nachala xxi vv. Avtoref. dis. na soiskanie nauch. stepeni kand. filolog. nauk : spec. 10.02.01 ,russkij yazyk”. Volgograd.

\section{Dictionaries and electronic databases}

DOEC $=$ Dictionary of Old English Corpus. [1981] 2009. Antonette diPaolo Healey with John Price Wilkin and Xin Xiang (compilers), The Dictionary of Old English Corpus Web Corpus, Tei-P5 Conformant Version. Toronto: University of Toronto Center for Medieval Studies DOE Project YCOE $=$ The York-Toronto-Helsinki Parsed Corpus of Old English Prose. 2003. Ann Taylor, Anthony Warner, Susan Pintzuk, Frank Beths (compilers). Department of Language and Linguistic. Science University of York Heslington. York England YO10 5DD. 